\title{
The effect of complementary food combinations on stunted children aged 6 months and over: a cross sectional study
}

\author{
*Nopi Nur Khasanah ${ }^{1}$, Hani Nurmalasari ${ }^{2}$, Elsa Nur Afiana ${ }^{2}$, Dyah Wiji Puspita Sari ${ }^{2}$, Apriliani Yulianti \\ Wuriningsih $^{3}$, Indra Tri Astuti ${ }^{3}$
}

Sri Lanka Journal of Child health, 2021; 50(3): 465-471

\begin{abstract}
Background: Complementary feeding practice, starting from when children are 6 months old, is one of the associated factors of stunted growth.
\end{abstract}

Objectives: To assess the correlation between complementary food combinations, mothers' occupation, basic immunisation history, birth weight and stunted growth.

Method: A cross-sectional study was conducted in Karangroto village, Central Java, Indonesia in November 2019. Data were collected using infant's weight and length/height and stunting was determined using WHO Child Growth Standards. Independent variable data were collected using a structured questionnaire. Bivariate analysis was performed using Chi-Squared and Fisher's exact test whilst multivariate analysis used logistic regression.

Result: Of the total 117 respondents, $24.8 \%$ were categorised as stunted and $37.3 \%$ children who did not receive different food combinations were categorised as stunted. Bivariate analysis found that stunting in children was related to unvaried food combinations $(\mathrm{p}=0.001$, OR 6.845 ; 95\% CI 2.199, 21.304), incomplete basic immunisations based on age $(\mathrm{p}=0.028$, OR $2.951 ; 95 \%$ CI $1.211,7.191)$ and low birth weight $(\mathrm{p}=0.032$, OR $3.344 ; 95 \%$ CI 1.150 , 9.720). Logistic regression showed that children

${ }^{1}$ Diploma Nursing Programme, Faculty of Nursing Science, Islamic University of Sultan Agung Semarang 50112, Indonesia, ${ }^{2}$ Nursing Profession Study Programme, Faculty of Nursing Science, Islamic University of Sultan Agung Semarang 50112, Indonesia, ${ }^{3}$ Nursing Study Programme, Faculty of Nursing Science, Islamic University of Sultan Agung Semarang 50112, Indonesia

*Correspondence: nopi.khasanah@unissula.ac.id

https://orcid.org/ 0000-0002-4519-318X

(Received on 03 September 2020: Accepted after revision on 16 October 2020)

The authors declare that there are no conflicts of interest

Personal funding was used for the project.

Open Access Article published under the Creative

Commons Attribution CC-BY (cc) who did not receive different food combinations were at a higher risk of experiencing stunting $(\mathrm{p}<0.001$, OR 12.355; 95\% CI 3.139, 48.629).

Conclusions: In this study stunting in children was significantly related to unvaried food combinations, incomplete basic immunisations based on age and low birth weight according to bivariate analysis. However, logistic regression showed that children who did not receive different food combinations were at a higher risk of stunting

DOI: https://dx.doi.org/10.4038/sljch.v50i3.9727

(Key words: Breastmilk, child nutrition, complementary feeding, stunting, different food combinations).

\section{Background}

Globally, about 156 million children are affected by stunting ${ }^{1}$. Indonesia is ranked as the fifth highest country for stunted children ${ }^{2}$. Data show that prevalence has now reached $30.8 \%$, comprising $19.3 \%$ children with stunted growth and $11.5 \%$ children classed as severely stunted ${ }^{3}$. Stunted children are considered more prone to sickness, a suboptimal intelligence quotient (IQ) score, physical and mental developmental disorders and poor health status ${ }^{4}$. Stunting often starts in utero and its severity increases, reaching a plateau at about two years of age $^{5}$. The first 1000 days of life is a critical period of growth and development. Parents and health professionals can optimise this period to prevent stunting through routine screening to detect children with a low height for their age ${ }^{6}$.

Nutritional requirements can be fulfilled starting from pregnancy. Exclusive breastfeeding is recommended up to the age of six months ${ }^{1}$. After six months, breastmilk alone is not sufficient to meet the nutritional requirements of infants ${ }^{7}$. Breastmilk is only sufficient to provide around half the total energy needs of infants aged 6-12 months and one third of energy needs between 12 and 24 months $^{8}$. Therefore, other foods and liquids are needed, along with breastmilk9 . Complementary food should be given appropriately according to the child's age, frequency, texture of the food, amount, as well as considering hygiene and ensuring there are variations in the food provided ${ }^{10}$. 
A preliminary study in Karangroto Village, Semarang City, Central Java Province, Indonesia found that 12 of 38 infants (30\%) had a Height-forAge Z score (HAZ) of $<-2$ SD on the Growth Chart. Studies on the factors related to stunting in that region have not been done before. It was therefore decided to conduct a study related to the causes of stunting so that appropriate community-based interventions could be soon implemented to reduce the incidence of stunting.

\section{Objectives}

To assess the correlation between complementary food combinations, mothers' occupation, basic immunisation history, birth weight and stunted growth

\section{Method}

This study used a cross-sectional design and was conducted from November to December 2019. Five out of 12 posyandu (pos pelayanan terpadu integrated service post in Indonesia) in Karangroto Village were chosen. In July 2018, Bangetayu Health Centre reported that there were more than $20 \%$ of children categorised as stunted in each of the five posyandu, which totalled 320 children aged 636 months.

Respondents in this study were mothers or nannies caring for children 6-36 months old.

Inclusion criteria of the respondents were:

- $\quad$ Age $>18$ years

- Actively involved in Family Planning Service Post-Integrated Health (Posyandu) activities

- $\quad$ Signed the informed consent

- Able to speak Bahasa Indonesia fluently

- Can remember the complementary food menus for one week within the time-span of the study conducted.

\section{Exclusion criteria were:}

- Children with chronic disease history or disability

- Mothers or nannies who could not remember the complementary food menus.

\section{Sample size:}

Total number of respondents needed was calculated based on the following formula:

$$
n=\frac{N Z_{1-\alpha / 2}^{2} P(1-P)}{N d^{2}+Z_{1-\alpha / 2}^{2} P(1-P)}
$$

$$
=\quad \frac{320(1.96)^{2} 0.5(1-0.5)}{320}=73.87=74+
$$

Anticipation of drop out $10 \%=81$ participants

After receiving the explanation of the study, respondents answered all questions in the questionnaire during 20-30 minutes. Researchers assisted and facilitated respondents during the filling out of the questionnaire.

Children's height measurement by microtoise and infants' length measurement by infantometer were carried out before determining categories. Height/age or length/age was determined by the WHO height-for-age Growth Chart and was categorised as normal if the Z-score was -2 SD, stunted if the Z-score was $-3 \mathrm{SD}$ up to $<-2 \mathrm{SD}$ and severely stunted if the Z-score was $<-3 \mathrm{SD}$.

Instrument of complementary food combinations: This was a questionnaire comprising questions regarding types of food consumed by the children every day for one week. It was filled out by mothers or nannies using the recall method.

Ethical issues: This study was approved by the Ethics Research Committee of Sultan Agung Islamic University, Semarang, Indonesia (No. 735/ A.I/FIK-SA/X/2019). Written informed consent was signed by respondents after they were given an explanation regarding procedures, rights and obligations during the research.

Statistical analysis: This was done with statistical software and encompassed univariate, bivariate and multivariate analysis. Univariate analysis was executed for each study variable descriptively using frequency and percentage. Chi-squared test and Fishers exact test were used in bivariate analysis to see correlation between independent variables and dependent variables. Multivariate analysis used logistic regression to analyse which variable was the most influential factor on prevalence of stunting in the Karangroto village.

\section{Results}

Respondents who were eligible based on inclusion criteria totalled 130 but only 117 filled in all of the questionnaire. Respondent response rate was around $90 \%$. Table 1 shows the stunting related factors in children aged 6-36 months. 
Table 1: Stunting related factors in children aged $6-36$ months $(\mathrm{n}=117)$

\begin{tabular}{|c|c|c|c|c|c|}
\hline \multirow[t]{2}{*}{ Variable } & \multicolumn{2}{|c|}{ Stunted } & \multirow[t]{2}{*}{ p-value } & \multirow[t]{2}{*}{ Odds ratio } & \multirow[t]{2}{*}{$95 \%$ CI } \\
\hline & Yes (\%) & No (\%) & & & \\
\hline $\begin{array}{l}\text { Mothers'age } \\
\text { Young adults } \\
\text { Middle-aged to older adults }\end{array}$ & $\begin{array}{l}05(17.2) \\
24(82.8)\end{array}$ & $\begin{array}{l}07(08) \\
81(92)\end{array}$ & $0.168 * *$ & 2.411 & $0.701-8.287$ \\
\hline $\begin{array}{l}\text { Mothers' education } \\
\text { High school or below } \\
\text { College or above }\end{array}$ & $\begin{array}{l}26(89.7) \\
03(10.3) \\
\end{array}$ & $\begin{array}{l}79(89.8) \\
09(10.2) \\
\end{array}$ & $1.000 * *$ & 0.987 & $0.248-3.924$ \\
\hline $\begin{array}{l}\text { Mothers' occupation } \\
\text { Working mothers } \\
\text { Full time housewives }\end{array}$ & $\begin{array}{l}16(55.2) \\
13(44.8) \\
\end{array}$ & $\begin{array}{l}62(70.5) \\
26(29.5) \\
\end{array}$ & $0.198 *$ & 0.516 & $0.218-1.224$ \\
\hline $\begin{array}{l}\text { Family income } \\
\text { Upah minimum regional or lower } \\
\text { Above Upah minimum regional }\end{array}$ & $\begin{array}{l}13(44.8) \\
16(55.2) \\
\end{array}$ & $\begin{array}{l}37(42) \\
51(58) \\
\end{array}$ & $0.963 *$ & 1.120 & $0.481-2.608$ \\
\hline $\begin{array}{l}\text { Family members } \\
>4 \text { people } \\
<=4 \text { people }\end{array}$ & $\begin{array}{l}07(24.1) \\
22(75.9)\end{array}$ & $\begin{array}{l}21(23.9) \\
67(76.1)\end{array}$ & $1.000^{*}$ & 1.015 & $0.380-2.709$ \\
\hline $\begin{array}{l}\text { Sanitation } \\
\text { Public } \\
\text { Private/at home } \\
\end{array}$ & $\begin{array}{l}02(06.9) \\
27(93.1) \\
\end{array}$ & $\begin{array}{l}01(01.1) \\
87(98.9) \\
\end{array}$ & $0.151 * *$ & 6.444 & $0.562-73.862$ \\
\hline $\begin{array}{l}\text { Mothers'BMI } \\
\text { Underweight } \\
\text { Normal-overweight }\end{array}$ & $\begin{array}{l}02(06.9) \\
27(93.1) \\
\end{array}$ & $\begin{array}{l}04(04.5) \\
84(95.5) \\
\end{array}$ & $0.637 * *$ & 1.556 & $0.270-8.968$ \\
\hline $\begin{array}{l}\text { Gender } \\
\text { Male } \\
\text { Female }\end{array}$ & $\begin{array}{l}14(48.3) \\
15(51.7)\end{array}$ & $\begin{array}{l}47(53.4) \\
41(46.6)\end{array}$ & $0.791 *$ & 1.228 & $0.530-2.846$ \\
\hline $\begin{array}{l}\text { Birth weight } \\
\text { Low } \\
\text { Normal }\end{array}$ & $\begin{array}{l}08(27.6) \\
21(72.4) \\
\end{array}$ & $\begin{array}{l}09(10.2) \\
79(89.8)\end{array}$ & $0.032 * *$ & 3.344 & $1.150-9.720$ \\
\hline $\begin{array}{l}\text { Breastfeeding histories } \\
\text { Not exclusive } \\
\text { Exclusive }\end{array}$ & $\begin{array}{l}13(44.8) \\
16(55.2)\end{array}$ & $\begin{array}{l}25(28.4) \\
63(71.6)\end{array}$ & $0.159 *$ & 2.048 & $0.861-4.868$ \\
\hline $\begin{array}{l}\text { Gestational age } \\
\text { Premature } \\
\text { Term } \\
\end{array}$ & $\begin{array}{l}11(37.9) \\
18(62.1) \\
\end{array}$ & $\begin{array}{l}37(42.0) \\
51(58.0)\end{array}$ & $0.863 *$ & 0.842 & $0.356-1.993$ \\
\hline $\begin{array}{l}\text { Children's age } \\
>2 \text { years old } \\
6-24 \text { months old }\end{array}$ & $\begin{array}{l}09(31.0) \\
20(69.0)\end{array}$ & $\begin{array}{l}45(51.1) \\
43(48.9)\end{array}$ & $0.095^{*}$ & 0.430 & $0.176-1.048$ \\
\hline $\begin{array}{l}\text { Basic immunisations history } \\
\text { Incomplete } \\
\text { Complete }\end{array}$ & $\begin{array}{l}13(44.8) \\
16(55.2) \\
\end{array}$ & $\begin{array}{l}19(21.6) \\
69(78.4) \\
\end{array}$ & $0.028 *$ & 2.951 & $1.211-7.191$ \\
\hline $\begin{array}{l}\text { Complementary food combinations } \\
\text { Unvaried } \\
\text { Varied }\end{array}$ & $\begin{array}{l}25(86.2) \\
04(13.8)\end{array}$ & $\begin{array}{l}42(47.7) \\
46(52.3)\end{array}$ & $0.001 *$ & 6.845 & $2.199-21.304$ \\
\hline
\end{tabular}

*bivariate test result with Chi-Square; **bivariate test result with Fisher's exact test

The most influential variable in stunting incidence Variables in bivariate analysis that got score $<0.25$ were included in logistic regression. They were mothers' age, mothers' education, sanitation, birth weight, breastfeeding history, children's age, basic immunisation history and complementary food combination. Table 2 show the analysis results of the multivariate logistic regression test. 
Table 2: Analysis results of the multivariate logistic regression test

\begin{tabular}{|c|c|c|c|c|c|c|c|}
\hline Variable & Coefficient & S.E & Wald & df & p-value & OR & $95 \% \mathrm{CI}$ \\
\hline Mothers' age & 0.608 & 0.783 & 0.604 & 1 & 0.437 & 1.837 & $0.396-8.516$ \\
\hline Mothers' occupation & -1.678 & 0.635 & 6.977 & 1 & 0.008 & $\mathbf{0 . 1 8 7}$ & $0.054-0.649$ \\
\hline Sanitation & 0.500 & 1.779 & 0.079 & 1 & 0.779 & 1.648 & $0.050-53.914$ \\
\hline Birth weight & 1.713 & 0.775 & 4.884 & 1 & 0.027 & 5.547 & $1.214-25.349$ \\
\hline Breastfeeding history & 0.927 & 0.588 & 2.490 & 1 & 0.115 & 2.528 & $0.799-7.999$ \\
\hline Children's age & -1.130 & 0.651 & 3.015 & 1 & 0.082 & 0.323 & $0.90-1.156$ \\
\hline Basic immunisation history & 0.504 & 0.616 & 0.671 & 1 & 0.413 & 1.656 & $0.495-5.538$ \\
\hline $\begin{array}{l}\text { Complementary food } \\
\text { combination }\end{array}$ & 2.514 & 0.699 & 12.934 & 1 & 0.000 & 12.355 & $3.139-48.629$ \\
\hline Constant & -2.231 & 0.761 & 8.558 & 1 & 0.003 & 0.107 & \\
\hline
\end{tabular}

SE: Standard error, OR odds ratio, CI confidence interval

\section{Discussion}

The majority of mothers in this study were in the adult-age group category. Mature parents are considered as having more experience in parenting so they realise that children are not miniature adults ${ }^{11}$. Every child is unique; they have their own strengths and weaknesses and different feelings as well ${ }^{12}$. Furthermore, mothers' age is related to psychological factors that include accepting the pregnancy and this influences parenting style, particularly regarding feeding patterns ${ }^{13}$. Educational background of mothers and feeding behaviour are closely related to nutritional status ${ }^{14}$. Information and knowledge of nutrition are more easily accepted by educated people ${ }^{15}$. However, it is possible for someone with a low educational background to have a better nutritional status ${ }^{15}$. In this digital era, information regarding ability of preparing food menus which fulfil balanced nutrition is easy to source.

Mothers can obtain a wealth of information from many sources and working mothers are considered to have easier access to it than housewives ${ }^{14}$. However, validity of information depends on the place where mothers work. Working mothers who love to share their experiences about how to care for children will enrich information for each other. Unfortunately, working mothers may have less time to implement their knowledge-related childcare ${ }^{16,17}$. This concern was conveyed by most respondents who were working mothers - they had to divide their time between work and childcare. Inappropriate childcare, like not paying attention to children's diet, can impact children's welfare causing nutritional problems ${ }^{15}$. A serious problem with children nowadays is stunting that can be led by family wellbeing status that is influenced by the total family members who need to be covered ${ }^{14}$. The number of family members can affect the distribution and provision of food in the family ${ }^{18}$. However, the total number of family members coupled with balanced and equal distribution and provision of food can decrease the risk of stunted children ${ }^{19}$. Food availability needs to be in line with adequate facilities and infrastructure to optimise growth and development of children ${ }^{20}$. Good sanitation is a factor related to health problems. Data in this study report that $2.6 \%$ (3 of 117) respondents still use shared/public sanitation. A previous study reported that some stunting is caused by poor sanitation and poor access to clean water ${ }^{21}$.

Theoretically, stunting begins in utero and continues for at least the first two years (1,000 days of life); therefore it is important to plan the pregnancy well. This study shows that most mothers were in the normal-overweight category. The crosstab results interestingly showed that more mothers were included in the underweight category and their children did not experience stunting. A previous study reported that the mothers' BMI influences more in terms of the wasting incidence and it is the mothers' height that influences the stunting incidence ${ }^{22}$. Over $50 \%$ of children in this study were 6-24 months old. The first two years of life is the golden period of children's growth and development. Inadequate nutrition can influence physical and intellectual growth, and result in a low quality of human resources in the future. Majority of child respondents in this study were male. Females usually grow faster than males but that is not significantly related to the causes of stunting in either males or females and both genders are equally likely to be at risk of stunting ${ }^{24}$.

The history of infant health status is also an important factor related to stunting incidence. Majority of respondents were exclusively breastfed. Breastmilk contains growth hormones that promote child growth and development in the baby's digestive system and protect them from bacteria and viruses ${ }^{25}$. Exclusive breastfeeding is essential for child growth because it prevents and decreases the likelihood of infectious disease in children ${ }^{26}$. Another important factor that emerged from the study is the history of preterm birth. Premature babies have growths delays due to a short gestational age and the lack of linear growth in the womb ${ }^{27}$. Term babies could also fail to thrive if they do not receive adequate nutrition. This will get worse when coupled with exposure to infectious diseases ${ }^{28}$. 
Fortunately, premature babies with growth faltering can catch up with normal growth if they receive adequate nutrition.

The multivariate analysis showed that the mothers' occupation does have a slight effect on stunting although the strength of the relationship was statistically very low. Moreover, bivariate analysis depicted that there was no significant relationship between mothers' occupation and stunting. A family's purchasing power to provide nutritional foods depends on the amount of family income. The index of household welfare is a factor that significantly correlates with stunting ${ }^{21}$. Data in this study showed that stunting in children was mostly experienced by those whose mothers work. Mothers' occupation can impact on children's feeding patterns further leading to inadequate nutrition in children ${ }^{25}$. Bivariate analysis figures showed a significant relationship between birth weight and stunting. Children with a low birth weight history coupled with inadequate nutritional intake experienced frequent infections during their growth $^{29}$. This gets worse when combined with a poor health service, further leading to stunted growth. Basic immunisations given to babies up to 9 months of age aim to prevent infections. Repeated infections can interfere with a child's growth and development if it happens over a long period of time $^{30}$. One previous study reported a significant relationship between immunisations and stunting ${ }^{31}$. Although BCG vaccine does not influence stunting in children its timing is crucial ${ }^{32}$; BCG is related to a lower risk of stunting if carried out in early life.

Complementary food combination is defined as the various kinds of complementary food consumed everyday by infants. This study noted that the kinds of food rarely consumed included vegetables and fruits $(42.3 \%)$, vegetable protein $(31.2 \%)$ and animal protein $(24.6 \%)$. In Indonesia there is a 4 star diet in complementary feeding practice including carbohydrate, animal protein, vegetable protein, fat, vegetables and fruits and also snacks ${ }^{10}$. This study showed that complementary food combination was the most significant factor leading to stunting. Correct complementary food combination can be seen in children who consume more protein ${ }^{33}$. In this study, children who consumed more carbohydrate and fat, compared to those who consumed animal and vegetable protein, experienced stunting. Children require approximately $1.5-2 \mathrm{~g}$ of protein for every $\mathrm{kg}$ of body weight. The amount of protein is considered adequate if it contains sufficient essential amino acids. Essential nutrition for children includes the correct amount of energy, protein, fat, water, vitamins and minerals. Each food component has a specific role in the growth and development of children. A previous study showed that there was a significant correlation between complementary food combinations and stunting, that is, if a food combination is provided that fulfils children's nutritional requirements then that can further prevent stunted growth ${ }^{7}$. Malnutrition can gradually be treated by increasing the consumption of good complementary food combinations because it is a good indicator of food quality and micronutrient density for children. Complementary feeding practice that is appropriate for age, meal frequency and time has an important role in determining complementary food quality. The fulfilment of the child's nutritional needs results in optimal growth and development.

\section{Conclusions}

In this study stunting in children was significantly related to unvaried food combinations, incomplete basic immunisations based on age and low birth weight according to bivariate analysis. However, logistic regression showed that children who did not receive different food combinations were at a higher risk of stunting

\section{References}

1. Hall C, Bennett C, Crookston B, Dearden $\mathrm{K}$, Hasan M, Linehan M, et al. Maternal knowledge of stunting in rural Indonesia. International Journal of Child Health and Nutrition 2018; 7(4):139-45. https://doi.org/10.6000/19294247.2018.07 .04 .2

2. TNP2K. 100 priority Regencies/ Cities for stunting interventions. I. TNP2K. Jakarta, Indonesia: National Team for the Acceleration of Poverty Reduction; 2017.

3. Kemenkes Balitbangkes. The primary result of Basic Health Research 2018. Ministry of Health of the Republic of Indonesia. Jakarta; 2018.

4. Setiawan E, Machmud R, Masrul. The related factors to stunting incidences in 24 to 59-month-old children in Andalas Public Health Centre, Padang Timur Sub District, Padang City in 2018. J FK unand. 2018; 7(2): 275-84.

https://doi.org/10.25077/jka.v7i2.813

5. PDTT K. A village pocketbook of stunting management. Jakarta: Underdeveloped Area Development, and Transmigration; 2017.

6. Hanieh S, Braat S, Simpson JA, Ha TTT, Tran TD, Tuan T, et al. The Stunting Tool for Early Prevention: Development and external validation of a novel tool to predict 
risk of stunting in children at 3 years of age. BMJ Global Health 2019; 4(6):1-12. https://doi.org/10.1136/bmjgh-2019001801

PMid: 31798990 PMCid: PMC6861113

7. Khamis AG, Mwanri AW, Ntwenya JE, Kreppel K. The influence of dietary diversity on the nutritional status of children between 6 and 23 months of age in Tanzania. BMC Pediatrics 2019; 19(1):19.

https://doi.org/10.1186/s12887-019-18975

PMid: 31881999 PMCid: PMC6935228

8. Prell C, Koletzko B. Breastfeeding and complementary feeding: recommendations on infant nutrition. Dtsch Arztebl Int. 2016; 113(25):435-44.

https://doi.org/10.3238/arztebl.2016.0435

PMid: 27397020 PMCid: PMC4941615

9. HHBF admin team. Mini encyclopedia of healthy complementary foods. Romadhona G, Ayuning, editors. Jakarta: Panda Media; 2017.

10. Ministry of Health of the Republic of Indonesia. A data window's bulletin and health information. In: Sakti ES, editor. Ministry of Health of the Republic of Indonesia. I. Jakarta: Ministry of Health of the Republic of Indonesia; 2018.

11. Gibson LC. Adult children of emotionally immature parents: How to heal if your parents couldn't meet your emotional needs. Oakland, Canada: New Harbinger Publications, Inc.; 2015.

12. Chetan S, Susheel K, Suvarna S. Every child is special. JOJ Nursing and Health Care 2018; 6(4).

https://doi.org/10.19080/JOJNHC.2018.06 .555693

13. Astuti DK. The correlation between the mother's characteristics and nutritional care, and under five stunting incidences in Hagorejo Village, Kulonprogo, DIY. Universitas Muhammadiyah Surakarta; 2016.

14. Iftikhar A, Bari A, Bano I, Masood Q. Impact of maternal education, employment and family size on nutritional status of children. Pakistan Journal of Medical Sciences 2017; 33(6):1401-5.

https://doi.org/10.12669/pjms.336.13689
PMid: 29492067 PMCid: PMC5768833

15. Mentari S, Hermansyah A. The related factors of the stunting status of 24 to 29month-old children in Siantan Hulu Public Health Centre Area. Pontianak Nutrition Journal 2018; 1(1):1-5. https://doi.org/10.30602/pnj.v1i1.275

16. Sahana H, Chandrashekar E. The study on "Mother's status in the family and nutritional status of their under five children" in Shimoga District of Karnataka. IOSR Journal of Nursing and Health Science 2016; 5(4):8-11. https://doi.org/10.9790/1959-0504030811

17. Dariya BL, Bafna G, Kholiya N. Effect of employment status of mother on the nutritional status of the pre-school children aged 2 to 5 years. International Journal of Basic and Applied Physiology 2016; 5(1): 2016.

18. Illahi RK. The correlation between family income, birth weight, and birth height and stunting incidences in under five children aged 24 to 29 months in Bangkalan. Manaj Kesehat Yayasan RS Dr, Soetomo. 2017; 3(1): 1-14.

https://doi.org/10.29241/jmk.v3i1.85

19. Aridiyah FO, Rohmawati N, Ririanty M. The influencing factors in stunting incidences in under five children in village and city areas. Pustaka Kesehat. 2015; 3(1): 163-70.

20. Zairinayati, Purnama R. The relationship between hygiene and environmental sanitation with the incidence of stunting in children under five. J Ilmial Multi Sci Kesehat. 2019; 10(1):78-91.

21. Aisyah, Suyatno, Rahfiludin MZ. The related factors to stunting in year one elementary students of SDI Taqwiyatul Wathon in commuter areas of Semarang City. J Kesehat Masy. 2019; 7(1):280-8.

22. Ali Z, Saaka M, Adams A-G, Kamwininaang SK, Abizari A-R. The effect of maternal and child factors on stunting, wasting and underweight among preschool children in Northern Ghana. BMC Nutrition 2017; 3(1). https://doi.org/10.1186/s40795-017-01542

PMid: 32153813 PMCid: PMC7050753 
23. Setyawati VAV. A stunting study based on age and sex in Semarang City. Univ Res Colloqium. 2018; 834-8.

24. Khan T, Khan REA, Raza MA. Gender analysis of malnutrition: A case study of school-going children in Bahawalpur. Asian Development Policy Review 2015; 3(2): 29-48.

https://doi.org/10.18488/journal.107/2015. 3.2/107.2.29.48

25. Wahdah S, Juffrie M, Huriyati E. The risk factors of stunting incidences in 6 to 36month-old children in the rural area of Silat Hulu Sub District, Kapuas Hulu. J Gizi dan Diet Indones 2016; 3(2):119. https://doi.org/10.21927/ijnd.2015.3(2).11 9-130

26. Mugianti S, Mulyadi A, Anam AK, Najah ZL. The causal factors of stunting in 25 to 60-month-old children in Sukorejo Sub District, Blitar City. J Ners dan Kebidanan 2018; 5(3): 268-78.

https://doi.org/10.26699/jnk.v5i3.ART.p2 $68-278$

27. Villar J, Giuliani F, Bhutta ZA, Bertino E, Ohuma EO, Ismail LC, et al. Postnatal growth standards for preterm infants: The preterm postnatal follow-up study of the INTERGROWTH-21stProject. Lancet Global Health 2015; 3(11): e681-91. https://doi.org/10.1016/S2214109X(15)00 163-1

28. Kusharisupeni. Growth faltering in infants in Indramayu, West Java. Makara Kesehat. $6: 1-5$.
29. Rahayu A, Yulidasari F, Putri AO, Rahman F. Birth weight history and stunting incidences in children under 2. J Kesehat Masy. 2015; 10(2): 67-73.

https://doi.org/10.21109/kesmas.v10i2.88 2

30. Permatasari DF, Sumarmi S. Differences of born body length, history of infectious diseases and development between stunting and non-stunting toddlers. $J$ Berk Epidemiol. 2018; 6(2):182.

https://doi.org/10.20473/jbe.V6I22018.18 2-191

31. Fajariyah RN, Hidajah AC. Correlation Between Immunization Status and Mother'S Height, and Stunting in Children 2-5 Years in Indonesia. $J$ Berk Epidemiol. 2020; 8(1):89.

https://doi.org/10.20473/jbe.V8I12020.8996

32. Berendsen MLT, Smits J, Netea MG, van der Ven A. Non-specific effects of vaccines and stunting: Timing may be essential. EBioMedicine 2016; 8:341-8. https://doi.org/10.1016/j.ebiom.2016.05.0 10

PMid: 27428443 PMCid: PMC4919612

33. Widyaningsih NN, Kusnandar K, Anantanyu S. Food diversity, feeding patterns and stunting incidences in 24 to 59-month-old children. $J$ Gizi Indones 2018; 7(1):22-9. https://doi.org/10.14710/jgi.7.1.22-29 